\title{
QUEEN'S
UNIVERSITY
BELFAST
}

\section{DDT uptake by arbuscular mycorrhizal alfalfa and depletion in soil as influenced by soil application of a non-ionic surfactant}

Wu, N. Y., Zhang, S. Z., Huang, H. L., Shan, X. Q., Christie, P., \& Wang, Y. S. (2008). DDT uptake by arbuscular mycorrhizal alfalfa and depletion in soil as influenced by soil application of a non-ionic surfactant. Environmental Pollution, 151(3), 569-575. https://doi.org/10.1016/j.envpol.2007.04.005

Published in:

Environmental Pollution

Queen's University Belfast - Research Portal:

Link to publication record in Queen's University Belfast Research Portal

\section{General rights}

Copyright for the publications made accessible via the Queen's University Belfast Research Portal is retained by the author(s) and / or other copyright owners and it is a condition of accessing these publications that users recognise and abide by the legal requirements associated with these rights.

Take down policy

The Research Portal is Queen's institutional repository that provides access to Queen's research output. Every effort has been made to ensure that content in the Research Portal does not infringe any person's rights, or applicable UK laws. If you discover content in the Research Portal that you believe breaches copyright or violates any law, please contact openaccess@qub.ac.uk. 


\title{
DDT uptake by arbuscular mycorrhizal alfalfa and depletion in soil as influenced by soil application of a non-ionic surfactant
}

\author{
Naiying $\mathrm{Wu}^{\mathrm{a}}$, Shuzhen Zhang ${ }^{\mathrm{a}, *}$, Honglin Huang ${ }^{\mathrm{a}}$, Xiaoquan Shan ${ }^{\mathrm{a}}$, \\ Peter Christie $^{\mathrm{b}}$, Youshan Wang ${ }^{\mathrm{c}}$ \\ a State Key Laboratory of Environmental Chemistry and Ecotoxicology, Research Center for Eco-Environmental Sciences, \\ Chinese Academy of Sciences, P.O. Box 2871, Beijing 100085, China \\ b Agricultural and Environmental Science Department, Queen's University Belfast, Newforge Lane, Belfast BT9 5PX, UK \\ ${ }^{\mathrm{c}}$ Municipal Academy of Agriculture and Forestry, Institute of Plant Nutrition and Resources, Beijing 100097, China
}

Received 13 November 2006; received in revised form 30 March 2007; accepted 8 April 2007

Combined colonization of alfalfa roots by an arbuscular mycorrhizal fungus and addition of non-ionic surfactant to the soil promoted root and shoot uptake and soil dissipation of DDT.

\begin{abstract}
A greenhouse pot experiment was conducted to investigate the colonization of alfalfa roots by the arbuscular mycorrhizal (AM) fungus Glomus etunicatum and application of the non-ionic surfactant Triton X-100 on DDT uptake by alfalfa and depletion in soil. Mycorrhizal colonization led to an increase in the accumulation of DDT in roots but a decrease in shoots. The combination of AM inoculation and Triton X-100 application enhanced DDT uptake by both the roots and shoots. Application of Triton X-100 gave much lower residual concentrations of DDT in the bulk soil than in the rhizosphere soil or in the bulk soil without Triton X-100. AM colonization significantly increased bacterial and fungal counts and dehydrogenase activity in the rhizosphere soil. The combined AM inoculation of plants and soil application of surfactant may have potential as a biotechnological approach for the decontamination of soil polluted with DDT.
\end{abstract}

(C) 2007 Elsevier Ltd. All rights reserved.

Keywords: Phytoremediation; Alfalfa; DDT; Glomus etunicatum; Triton X-100

\section{Introduction}

Contamination of soils by persistent organic pollutants (POPs) is a widespread environmental problem and their removal from soil has become a major concern. As a result, remediation methodologies are of significant interest and considerable attention has been focused on phytoremediation due to its convenience, cost-effectiveness and environmental acceptability (Suresh and Ravishankar, 2004).

The organochloride insecticide dichlorodiphenyltrichloroethane (DDT, 1,1,1-trichloro-2,2,bis( $p$-chlorophenyl)-ethane)

\footnotetext{
* Corresponding author. Tel.: +86 1062849683 ; fax: +86 1062923563 . E-mail address: szzhang@ @rcees.ac.cn (S. Zhang).
}

was used throughout the world for several decades to control arthropod disease vectors and agricultural pests. Soil DDT contamination levels up to $7.5 \mathrm{mg} \mathrm{kg}^{-1}$ have been reported (Kantachote et al., 2004). Although its use in agriculture was banned in China in 1983, unfortunately, it appears that its residues and metabolites DDD (1,1-dichloro-2,2-bis ( $p$ chlorophenyl)ethane) and DDE (1,1-dichloro-2,2-bis ( $p$-chlorophenyl) ethylene) are still widely distributed in soils. China still has two production plants producing DDT as an intermediate for dicofol production and control of malaria ( $\mathrm{Li}$ et al., 2006). There is a wealth of information demonstrating that POPs such as DDT have low availability/mobility because of their sequestration or weathering in soil. Nonetheless, there have been some greenhouse and field-scale studies of weathered DDT or DDE uptake in a range of plants with accumulation 
concentrations at the $\mathrm{m} \mathrm{kg}^{-1}$ level (Lunney et al., 2004; White, 2002; White et al., 2006). Extensive information exists on the negative effects of DDT and its metabolites on the environment and on human health (Vieira et al., 2001; Binelli and Provini, 2003).

Arbuscular mycorrhizal (AM) fungi are ubiquitous in terrestrial ecosystems, forming symbiotic associations with roots of the majority of plant species (Smith and Read, 1997). The ubiquity of AM fungi, their capacity to enhance the tolerance of host plants to organic contaminants, and their interactions with soil microorganisms in the rhizosphere have led to recent studies on their interactions with organic pollutants in the context of phytoremediation (Joner and Leyval, 2003a; Huang et al., 2007). Research has established that AM fungi can enhance the growth of several plant species in soil with high polycyclic aromatic hydrocarbon (PAH) concentrations (Leyval and Binet, 1998). Experimental evidence has been obtained for the impact of AM on the uptake and dissipation of some organic pollutants in soil such as PAHs and atrazine (Joner and Leyval, 2003b; Huang et al., 2007). These studies indicated that AM fungi conferred some benefit on phytoremediation of soils contaminated with organic pollutants.

The POPs in soil usually exhibit limited bioavailability to both microorganisms and plants due to their strong affinity to the soil matrix, especially soil organic matter (Chen et al., 2005). Phytoremediation of soils contaminated with POPs is thus hindered by sorption of the pollutants to soil organic matter and their low aqueous solubility (Boldrin et al., 1993; Stucki and Alexander, 1987). Solubilization agents such as surfactants have been added to soil to enhance the release of POPs from the sorbed phase and, thereby, to increase their aqueous concentrations and bioavailability (Zhou and Zhu, 2005). Although addition of surfactants has been explored in the cleanup of contaminated soils (Zhu et al., 2003), there are few reports of their application in phytoremediation. We hypothesized that the combined application of AM fungi and surfactants to be an effective strategy for soil phytoremediation owing to the enhanced mobility of POPs in the soil due to the surfactants, together with increased degradation and plant uptake of the POPs as well as improved plant establishment due to mycorrhizal colonization.

In the present study we investigated the effects of AM fungal inoculation and the combined effects of AM fungal inoculation and soil application of the surfactant Triton X-100 on DDT uptake by alfalfa, dissipation of DDT and its metabolites and the enzyme activities and microbial populations in a soil which was artificially contaminated with various levels of DDT. The aim was to evaluate the potential of AM inoculation and surfactant application to soil for the phytoremediation of POPs.

\section{Materials and methods}

\subsection{Experimental design}

A pot experiment was conducted in which non-mycorrhizal and mycorrhizal plants with no soil application of surfactant and AM-inoculated plants grown in soil amended with the non-ionic surfactant Triton X-100 was compared. The soil was spiked with high purity DDT (98\% purity, Aldrich Chemical) dissolved in hexane to give application rates of $0.0,2.5,5.0$ and $10.0 \mathrm{mg} \mathrm{kg}^{-1}$ and $10 \mathrm{~mL}$ Triton $\mathrm{X}-100$ was added to each pot as a $0.065 \mathrm{~g} \mathrm{~mL}^{-1}$ solution to reach $0.1 \%(\mathrm{w} / \mathrm{w})$ in the soil. The treatments were set up in triplicate.

\subsection{Soil preparation}

A loamy soil was collected from the surface $(0-15 \mathrm{~cm}$ depth) of an experimental field at Beijing Academy of Agriculture and Forest Sciences. The selected characteristics are as follows: silt, 45\%; clay, 23\%; sand, 32\%; pH, 7.74 (1:2, soil/water); organic matter, $2.7 \%$; $\mathrm{NaHCO}_{3}$-extractable $\mathrm{P}, 3.9 \mathrm{mg} \mathrm{kg}^{-1}$; C, $1.95 \%$; N, $0.24 \%$; cation exchange capacity, $25.6 \mathrm{cmol} \mathrm{kg}^{-1}$; and an initial DDT concentration of $0.13 \mathrm{mg} \mathrm{kg}^{-1}$. Soil cation exchange capacity was analyzed using the method of Rhodes (1982). Other soil characteristics were determined following the methods described by Srivastava (1992). The soil was air-dried, ground and passed through a 2-mm nylon sieve. It was then mixed with sand $(1-2 \mathrm{~mm})$ in a ratio of $1: 1(\mathrm{w} / \mathrm{w})$ to produce the growth medium. The soil mixture (henceforth referred to as the soil) was sterilized by $\gamma$-radiation (10 kGy, $10 \mathrm{MeV} \gamma$-rays) to inactivate $\mathrm{AM}$ fungi and received mineral nutrients at rates of $30 \mathrm{mg} \mathrm{P}\left(\mathrm{KH}_{2} \mathrm{PO}_{4}\right), 60 \mathrm{mg} \mathrm{N}\left(\mathrm{NH}_{4} \mathrm{NO}_{3}\right)$, and $67 \mathrm{mg} \mathrm{K}$ $\left(\mathrm{K}_{2} \mathrm{SO}_{4}\right) \mathrm{kg}^{-1}$ soil. It was then artificially spiked with DDT with thorough mixing. The soils were allowed to dry in a fume hood for 3 days. During this period the soil samples were shaken three times a day in order to mix the compounds with the soil thoroughly and to increase the hexane volatilization rate. Finally, the soils were shaken, homogenized and incubated for 4 weeks at room temperature. We left a plate in the growth chamber with some resin inside as adsorbent to test the volatilization of DDT.

\subsection{Inoculum and host plants}

Inoculum of the AM fungus Glomus etunicatum (BGC USA01) was propagated for 10 weeks in pot culture on broomcorn (Sorghum vulgare Pers.) plants grown in a loamy soil in a greenhouse. The inoculum, which was airdried and passed through a 2-mm sieve, consisted of spores, mycelium, sandy soil and root fragments containing approximately 350 spores $^{-1}$ soil (dry weight soil basis).

Alfalfa seeds (Medicago sativa L.) were purchased from the Chinese Academy of Agricultural Sciences, Beijing, China. They were surface sterilized in a $10 \%(\mathrm{v} / \mathrm{v})$ solution of hydrogen peroxide for $10 \mathrm{~min}$, rinsed with sterile distilled water and pre-germinated on moist filter paper overnight and were then ready for sowing.

\subsection{Pot experiment}

Each pot received $650 \mathrm{~g}$ of incubated soil and was equilibrated in a growth chamber for $4 \mathrm{~d}$ at $70 \%$ of water holding capacity. Seven pre-germinated alfalfa seeds were sown in each pot and thinned to four seedlings after growth for $7 \mathrm{~d}$. Mycorrhizal treatments received $50 \mathrm{~g}$ of the fungal inoculum by mixing with about $200 \mathrm{~g}$ of soil and then placing the mixture in the middle layer of the plant pots. In the non-mycorrhizal treatments the inoculum was replaced by an equivalent amount of sterilized soil-sand mixture. For the treatments with surfactant, Triton X-100 was watered into the soil after sowing to give a concentration of $0.1 \%(\mathrm{w} / \mathrm{w})$. The pots were positioned randomly in the growth chamber and re-randomized every 2 days. The experiment was conducted in a controlled-environment growth chamber with a photoperiod of $14 \mathrm{~h}$ at a light intensity of $250 \mu \mathrm{mol} \mathrm{m} \mathrm{m}^{-2} \mathrm{~s}^{-1}$ provided by supplementary illumination. The day/night temperature regime was $25^{\circ} \mathrm{C} / 20^{\circ} \mathrm{C}$ and the relative humidity was maintained at $70 \%$. Distilled water was added as required to maintain soil moisture content at $70 \%$ of water holding capacity by regular weighing. Nitrogen fertilizer (as $\mathrm{NH}_{4} \mathrm{NO}_{3}$ ) was added to each pot 30 and $45 \mathrm{~d}$ after sowing to provide a total of $120 \mathrm{mg} \mathrm{N}$ per pot. 


\subsection{Sample preparation}

Plants were harvested after growth for $60 \mathrm{~d}$. Pots were left unwatered for $2 \mathrm{~d}$ prior to harvest. Shoots and roots were harvested separately. Any part of the plant above the soil surface was considered as shoot material and the part below the soil surface was included in the roots. Root fragments were collected by sieving the soil and adding them to the root samples. Roots were first carefully washed with tap water to remove any adhering soil particles. Then roots and shoots were rinsed thoroughly with distilled water, blotted dry and weighed. Soils were then sampled from each pot. Bulk soil was collected by gently crushing the soil and shaking the roots. The soil that adhered to the root system was obtained by shaking the roots and operationally defined as rhizosphere soil (Lynch, 1990). For enumeration of bacteria and fungi, rhizosphere soil sub-samples were stored at $4{ }^{\circ} \mathrm{C}$ for microbial assays and were performed within a week. A portion of fresh root sub-sample was taken from each treatment for the determination of the proportion of root length colonized by the AM fungus. Soil samples and the remainder of the plant samples were freeze-dried, weighed, and stored at $4{ }^{\circ} \mathrm{C}$. Some freeze-dried plant samples were weighed, oven dried at $105^{\circ} \mathrm{C}$ for $24 \mathrm{~h}$ and re-weighed, and the differences between the oven dry weights and the freeze-dried weights were found to be negligible.

\subsection{Adsorption of DDT on roots}

Adsorption of DDT on roots was carried out in batch equilibration sorption experiments. Three milligram of freeze-dried roots from both inoculated and uninoculated treatments, from the non-spiked soil, were placed in 50-mL glass centrifuge tubes containing $35 \mathrm{~mL}$ of distilled water saturated with $7 \mu \mathrm{g} \mathrm{L}^{-1}$ DDT. They were then sealed with Teflon-lined screw caps and incubated for $0.5,1.5,5,10,24$, and $48 \mathrm{~h}$ on a reciprocating shaker at $25^{\circ} \mathrm{C}$. Thirty milliliter of the sample solutions were taken at different time intervals after centrifuging for $20 \mathrm{~min}$ at $4000 \mathrm{rpm}$ and extracted with $1 \mathrm{~mL}$ hexane in preparation for DDT analysis. The adsorption experiment was carried out in triplicate and the results were expressed as percentage of DDT adsorbed on roots.

\subsection{Assessment of AM colonization of alfalfa roots}

The proportion of total root length colonized by the AM fungus was assessed by cutting a random sub-sample of $1 \mathrm{~g}$ fresh roots into 0.5- to 1.0$\mathrm{cm}$-long segments. Root segments were cleaned in $10 \% \mathrm{KOH}$ for $10 \mathrm{~min}$ at $90{ }^{\circ} \mathrm{C}$ in a water bath, rinsed in water, and then stained with $0.1 \%$ Trypan blue for 3-5 min at $90{ }^{\circ} \mathrm{C}$ in a water bath. Mycorrhizal colonization was determined by the grid line intersect method (Giovannetti and Mosse, 1980).

\subsection{DDT analysis}

All soil samples were subjected to Soxhlet extraction. One gram of soil was placed in a cellulose extraction thimble with an equivalent quantity of anhydrous sodium sulphate and extracted with $100 \mathrm{~mL}$ of hexane/acetone mixture $(1: 1, \mathrm{v} / \mathrm{v})$ for $24 \mathrm{~h}$. A cleanup step prior to analysis was mandatory in order to improve detection and quantification limits and to extend the column lifetime. The cleanup was done using a modification of the method of Gong et al. (2004). Briefly, the sample extract was transferred to a separating funnel and cleaned with $6 \mathrm{~mL}$ of concentrated sulfuric acid three times, then cleaned three times with $30 \mathrm{~mL} 2 \% \mathrm{Na}_{2} \mathrm{SO}_{4}$ aqueous solution and dried by passing through a column packed with $2 \mathrm{~g}$ of anhydrous $\mathrm{Na}_{2} \mathrm{SO}_{4}$. Finally, it was concentrated and ready for DDT analysis.

The same Soxhlet extraction was conducted on the tissue samples after they were chopped with pruning shears and ground up using a mortar and pestle, by which we obtained the contents of DDT inside the roots plus the DDT absorbed on the root surface. In order to detect the DDT fraction on the root surface, a sequential extraction was carried out before the Soxhlet extraction using a modification of the method of Chen et al. (2007). Three grams of mycorrhizal and non-mycorrhizal fresh roots from soil spiked with $10 \mathrm{mg} \mathrm{kg}^{-1}$ DDT were washed with distilled water and placed in $50 \mathrm{~mL}$ glass centrifuge tubes with Teflon-lined screw caps. They were then extracted with $20 \mathrm{~mL}$ of $0.01 \mathrm{~mol} \mathrm{~L}^{-1}$ $\mathrm{CaCl}_{2}$ for $2 \mathrm{~h}$ and the bulk solution then filtered. The filtrate was extracted twice with $20 \mathrm{~mL}$ hexane and the extracts were concentrated in a rotary evaporator. The $\mathrm{CaCl}_{2}$ fraction represented DDT dissolved in the aqueous solution within the apparent free space of the roots. The fraction representing the DDT strongly adsorbed on the root surface was extracted with $20 \mathrm{~mL}$ hexane for $2 \mathrm{~h}$. The hexane solution was then purified using the same method as that used for soils and plant tissues. Following the hexane extraction, the root tissues were freezedried, ground and subjected to Soxhlet extraction.

Extracts were analyzed using an Agilent $6890 \mathrm{GC}$ equipped with a ${ }^{63} \mathrm{Ni}$ electron capture detector and a capillary column $(30 \mathrm{~m} \times 0.25 \mu \mathrm{m} \times 0.32 \mathrm{~mm})$. The column oven was programmed from an initial temperature of $80^{\circ} \mathrm{C}$ to $240{ }^{\circ} \mathrm{C}$ at a rate of $20^{\circ} \mathrm{C} \mathrm{min}^{-1}$, held for $1 \mathrm{~min}$, and then ramped at a rate of $8^{\circ} \mathrm{C} \mathrm{min}^{-1}$ to $280^{\circ} \mathrm{C}$ with a final hold time of $1 \mathrm{~min}$. The detector and injector were maintained at 280 and $220^{\circ} \mathrm{C}$, respectively, and the injector was in the splitless mode. Nitrogen was the carrier gas at $1 \mathrm{~mL} \mathrm{~min}^{-1}$. Injection volume was $1 \mu \mathrm{L}$ in $n$-hexane. Recoveries for the extraction procedure and GC analysis were tested by spiking a proportion of DDT into the soil and the ground plant materials which were then incubated for $60 \mathrm{~d}$. The recoveries averaged $90.3 \%$ with an $\operatorname{RSD}<4.5 \%(n=5)$.

\subsection{Microbial enumeration and determination of enzyme activities}

Culturable bacterial and fungal counts were made using the plate count method. Microbial counts were determined by means of three replicate rhizosphere soil samples. Plate counts of bacteria and fungi were estimated from $10^{-6}$ and $10^{-3}$ dilutions plated on beef extract peptone and Martin's medium which were incubated at $30^{\circ} \mathrm{C}$ for $2 \mathrm{~d}$ and $5 \mathrm{~d}$, respectively. After incubation the numbers of bacterial cells and fungi were counted.

Rhizosphere dehydrogenase activity was assayed using a modification of the method of Dick et al. (1996). Six grams of rhizosphere soil were thoroughly mixed with $0.06 \mathrm{~g} \mathrm{CaCO}_{3}$ and three replicate samples were placed in test tubes and $3 \mathrm{~mL}$ of $1 \% 2,3,5$-triphenyltetrazolium chloride (TTC) and $2.5 \mathrm{~mL}$ distilled water were added. Samples were incubated at $37^{\circ} \mathrm{C}$ for $24 \mathrm{~h}$ and then $10 \mathrm{~mL}$ methanol added to each tube and the samples were vortexed. The soil suspensions were then filtered and the filtrates were diluted with methanol to $50 \mathrm{~mL}$. The color's intensity was measured at $485 \mathrm{~nm}$ using a spectrophotometer. Dehydrogenase activities in the samples were calculated using calibration curves prepared from 2, 5, 10, and 20 and $30 \mu \mathrm{g}$ triphenyl formazan (TPF) $\mathrm{mL}^{-1}$ standards. Results are presented as $\mathrm{mg} \mathrm{TPF} \mathrm{g}^{-1}$ soil.

\subsection{Data analysis}

Data were subjected to two-way analysis of variance using the SPSS version 10.0 software package to determine the significance of soil DDT concentration and AM inoculation with or without the surfactant as sources of variation. Comparisons between means were carried out using Duncan's multiple range test at a significance level of $p<0.05$.

\section{Results}

\subsection{Root colonization and plant biomass}

Table 1 displays the mycorrhizal colonization and biomass of alfalfa after growth for $60 \mathrm{~d}$. No mycorrhizal colonization was observed in the roots of uninoculated plants. Mycorrhizal colonization of the roots of inoculated plants decreased from 70.3 to $49.7 \%$ with increasing DDT concentration from 0 to $10 \mathrm{mg} \mathrm{kg}^{-1}$. Mycorrhizal root colonization varied from 66.2 to $49.1 \%$ for the treatments that included Triton X-100. Mycorrhizal plants had higher shoot yields and lower root yields than non-mycorrhizal controls with only one exception when DDT was applied at $10 \mathrm{mg} \mathrm{kg}^{-1}$. DDT application generally increased shoot and root biomass and application of Triton 
Table 1

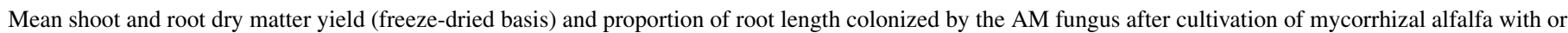
without surfactant and non-mycorrhizal controls in soil containing different levels of added DDT $\left(\mathrm{mean}^{\mathrm{a}} \pm \mathrm{SE}, n=3\right.$ )

\begin{tabular}{|c|c|c|c|c|}
\hline $\begin{array}{l}\text { Initial DDT } \\
\text { addition }\left(\mathrm{mg} \mathrm{kg}^{-1}\right)\end{array}$ & $\begin{array}{l}\text { Mycorrhizal status/surfactant } \\
\text { addition }\end{array}$ & $\begin{array}{l}\text { Shoot weight } \\
\left(\mathrm{g} \mathrm{pot}^{-1}\right)\end{array}$ & $\begin{array}{l}\text { Root weight } \\
\left(\mathrm{g} p o t^{-1}\right)\end{array}$ & $\begin{array}{l}\text { Mycorrhizal colonization }{ }^{\mathrm{b}} \\
(\%)\end{array}$ \\
\hline 0.0 & $\begin{array}{l}\text { Non-mycorrhizal } \\
\text { Mycorrhizal } \\
\text { Mycorrhiza + surfactant }\end{array}$ & $\begin{array}{l}0.91 \pm 0.04 \mathrm{~g} \\
1.16 \pm 0.07 \mathrm{bd} \\
0.82 \pm 0.03 \mathrm{gh}\end{array}$ & $\begin{array}{l}0.70 \pm 0.03 \mathrm{c} \\
0.65 \pm 0.06 \mathrm{fh} \\
0.56 \pm 0.01 \mathrm{~g}\end{array}$ & $\begin{array}{l}0.0 \\
70.3 \pm 1.29 a \\
66.2 \pm 0.83 b\end{array}$ \\
\hline 2.5 & $\begin{array}{l}\text { Non-mycorrhizal } \\
\text { Mycorrhizal } \\
\text { Mycorrhiza + surfactant }\end{array}$ & $\begin{array}{l}1.16 \pm 0.09 \mathrm{bcdef} \\
1.29 \pm 0.01 \mathrm{abde} \\
1.05 \pm 0.05 \mathrm{efg}\end{array}$ & $\begin{array}{l}0.74 \pm 0.10 \mathrm{~d} \\
0.66 \pm 0.09 \mathrm{eh} \\
0.62 \pm 0.02 \mathrm{bcdefgh}\end{array}$ & $\begin{array}{l}0.0 \\
68.5 \pm 0.57 \mathrm{a} \\
59.2 \pm 3.03 \mathrm{c}\end{array}$ \\
\hline 5.0 & $\begin{array}{l}\text { Non-mycorrhizal } \\
\text { Mycorrhizal } \\
\text { Mycorrhiza + surfactant }\end{array}$ & $\begin{array}{l}1.14 \pm 0.12 \mathrm{de} \\
1.34 \pm 0.11 \mathrm{ac} \\
1.37 \pm 0.08 \mathrm{ab}\end{array}$ & $\begin{array}{l}1.06 \pm 0.06 \mathrm{a} \\
0.63 \pm 0.09 \mathrm{f} \\
0.84 \pm 0.13 \mathrm{~b}\end{array}$ & $\begin{array}{l}0.0 \\
52.7 \pm 2.52 \mathrm{~d} \\
51.3 \pm 3.27 \mathrm{~d}\end{array}$ \\
\hline 10.0 & $\begin{array}{l}\text { Non-mycorrhizal } \\
\text { Mycorrhizal } \\
\text { Mycorrhiza + surfactant }\end{array}$ & $\begin{array}{l}1.23 \pm 0.04 \mathrm{abdef} \\
1.39 \pm 0.04 \mathrm{a} \\
1.00 \pm 0.05 \mathrm{fh}\end{array}$ & $\begin{array}{l}0.82 \pm 0.03 \mathrm{bcd} \\
0.85 \pm 0.06 \mathrm{abcde} \\
0.79 \pm 0.06 \mathrm{c}\end{array}$ & $\begin{array}{l}0.0 \\
49.5 \pm 2.53 \mathrm{~d} \\
49.2 \pm 1.22 \mathrm{~d}\end{array}$ \\
\hline \multicolumn{5}{|l|}{ Significance of } \\
\hline \multicolumn{2}{|l|}{ DDT level } & $\begin{array}{l}* * * \\
* * *\end{array}$ & $\begin{array}{l}* * * \\
* * *\end{array}$ & $\begin{array}{l}* * * \\
* * *\end{array}$ \\
\hline \multicolumn{2}{|c|}{ DDT $\times$ mycorrhizal status/surfactant } & $*$ & $* * *$ & $* * *$ \\
\hline
\end{tabular}

*Significant by analysis of variance at $p<0.05$.

$* * *$ Significant by analysis of variance at $p<0.001$.

a Values followed by the same letter within a column are not significantly different according to Duncan's multiple range test at the 5\% level.

b Colonization of NM pants was $0 \%$, it was therefore excluded from statistical analysis of effects of DDT/surfactant on mycorrhizal colonization.

X-100 decreased them. Although these yield effects were statistically significant they were numerically small.

\subsection{Accumulation of DDT in plants}

DDT accumulation in alfalfa is shown in Fig. 1. Roots accumulated much more DDT than did shoots. DDT concentrations in both shoots and roots increased markedly with increasing DDT application rate to soil irrespective of inoculation treatment. AM inoculated roots accumulated consistently more DDT than non-mycorrhizal roots. Addition of Triton X-100 led to increased DDT concentrations in roots. Mycorrhizal plants showed lower shoot DDT accumulation than non-mycorrhizal controls, but application of Triton X-100 to the soil significantly elevated DDT accumulation in the shoots $(p<0.05)$.

\subsection{Dissipation of DDT in soils}

Negligible changes in the DDT concentration in the spiked soils were detected after aging for 4 weeks. After harvest, only DDT was detected in the bulk soil samples but the two metabolites DDD and DDE were detected in the rhizosphere soils from all treatments (Fig. 2). However, the concentrations were very low and no clear differences in concentrations could be detected among the different treatments. The DDT concentrations in soil decreased markedly compared with the initial levels and this effect was more pronounced in the rhizosphere soil than in the bulk soil. A $66.8-95.4 \%$ reduction of the initially added DDT was observed in the rhizosphere soils compared to $13.1-64.8 \%$ in the bulk soils. An interesting observation was that in the presence of Triton X-100 the DDT residual concentrations were much lower in the bulk soils than in the rhizosphere soils as well as in bulk soils without Triton $\mathrm{X}-100$ application. For instance, when $10.0 \mathrm{mg} \mathrm{kg}^{-1}$ of DDT was added to the soil, the DDT concentration decreased to $27.3 \%$ of the original level in the bulk soil compared to $87.8 \%$ in the bulk soil in the absence of Triton X-100 and $47.3 \%$ in the rhizosphere soil in the presence of Triton X-100.

\subsection{DDT adsorption on roots}

DDT sorption on mycorrhizal and non-mycorrhizal roots increased rapidly during the first $5 \mathrm{~min}$ and then remained constant (Fig. 3). A maximum of up to $79.6 \%$ of DDT was sorbed on mycorrhizal roots compared to $80.3 \%$ on non-mycorrhizal roots. DDT sorption on non-mycorrhizal and on mycorrhizal roots was not significantly different $(p>0.05)$.

\subsection{Microbial assays and dehydrogenase activities}

Soil microbial counts and dehydrogenase activities in rhizosphere soil varied among the treatments (Table 2). Total culturable bacteria and fungi varied from $1.0 \times 10^{7}$ to $3.4 \times$ $10^{7}$ cells $\mathrm{g}^{-1}$ and $2.8 \times 10^{7}$ to $4.4 \times 10^{7}$ cells g ${ }^{-1}$. The mean bacterial numbers were at least three orders of magnitude higher than the fungal counts. AM inoculation significantly increased bacterial and fungal counts. Dehydrogenase activity changed in a similar way to the counts of soil microorganisms.

\section{Discussion}

A major finding of the present study is the impact that AM fungal colonization and Triton X-100 had on the accumulation of DDT in alfalfa roots and shoots. We hypothesized that such 

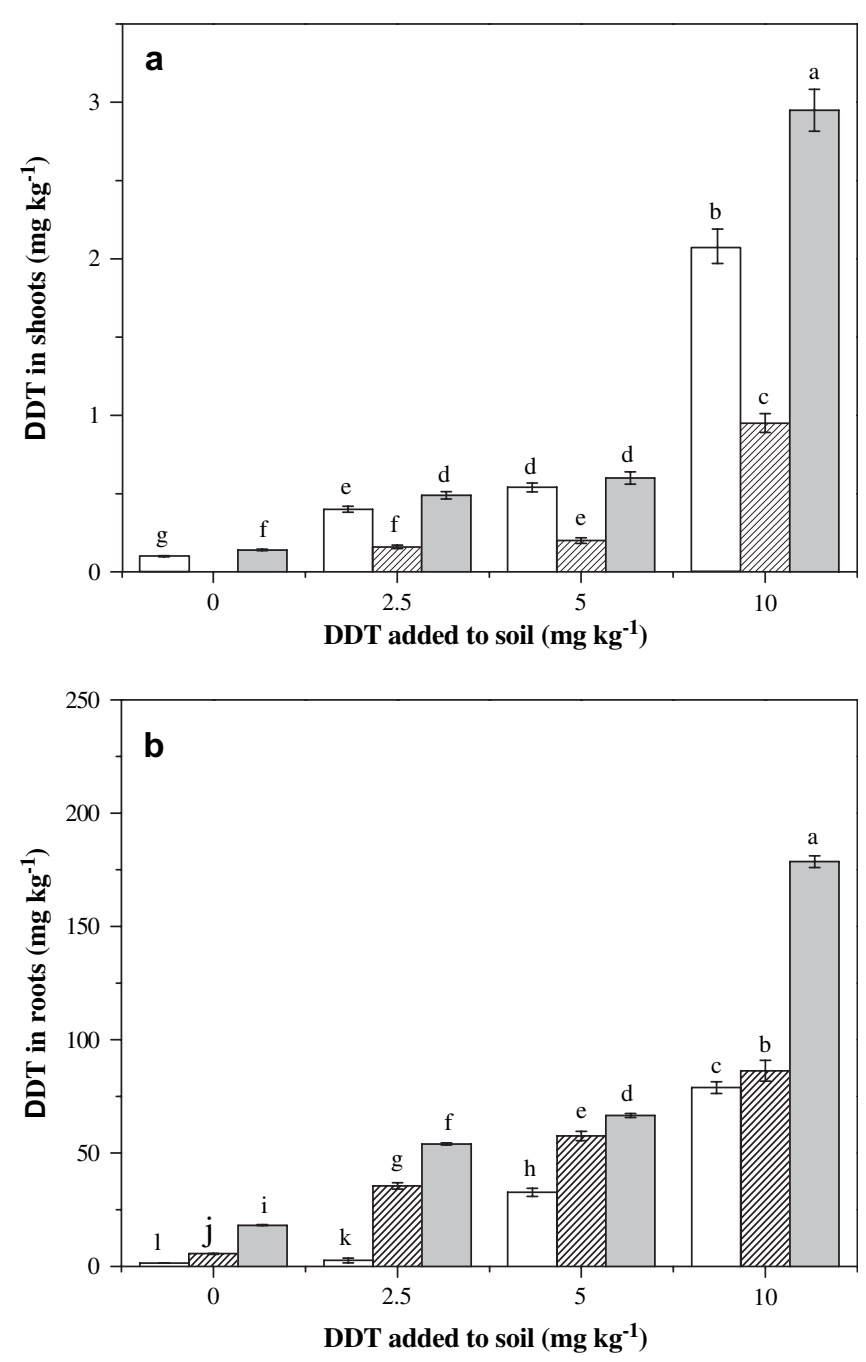

Fig. 1. DDT concentrations in alfalfa (a) shoot and (b) root tissues by Soxhlet extraction. Data are means of three replicates and on a dry matter (freezedried) basis. Non-mycorrhizal ( $\square$ ); Mycorrhizal (ש্]T); Mycorrhi$\mathrm{za}+$ surfactant $(\square)$. Bars, standard errors. Values followed by the same letter are not significantly different according to Duncan's multiple range test at the $5 \%$ level.

an observation might be attributable mainly to an increase in the adsorption of DDT on colonized roots. In order to test this hypothesis we examined DDT sorption by excised root tissues and found that DDT adsorption was consistently higher on non-mycorrhizal than on mycorrhizal roots. There was no significant difference between mycorrhizal and non-mycorrhizal plants at the 5\% level (Fig. 3). The adsorption experiment had some limitations due to the low solubility of DDT in water and it was not possible to elucidate the sorption behavior of DDT at high concentrations by experiment or by isotherm model prediction. We therefore proceeded to use a sequential extraction procedure with $\mathrm{CaCl}_{2}$ and hexane to extract DDT from the fresh roots harvested from the soil spiked with $10 \mathrm{mg} \mathrm{kg}^{-1}$ DDT before Soxhlet extraction in order to clarify the impact of AM fungal colonization on the affinity of roots for DDT. The $\mathrm{CaCl}_{2}$ extract fraction, which was considered as loosely adsorbed on root surfaces, was too low to be detected.
The hexane fraction (strongly adsorbed fraction) of DDT accounted for $5.6 \%$ and $17.2 \%$ of the total amount of DDT in mycorrhizal and non-mycorrhizal roots, respectively. This result confirms that sorption and sequestration of DDT was higher on mycorrhizal roots than on non-mycorrhizal roots and it might be ascribed to the formation of abundant extraradical mycelium (Joner et al., 2001) which has a high affinity with hydrophobic organic compounds. The combination of mycorrhizal inoculation and the surfactant Triton X-100 increased DDT accumulation in both roots and shoots. Fig. 1 shows much greater DDT accumulation in the roots in the presence of Triton X-100, especially at the highest DDT dose rate studied, which may have contributed to the increase in DDT translocation to the shoots. Another possible explanation for the enhanced accumulation of DDT in mycorrhizal roots could be an increase in the mobility and bioavailability of the contaminant in soil. It is possible that the AM fungus stimulated the mineralization of DDT in the soil via its effects on soil organisms as can be seen from the difference in bacterial counts, which in turn may have led to the changes in DDT availability. However, elucidation of any direct effect needs to be addressed by further work.

After plants' harvest the total residual concentrations of DDT in soil decreased significantly (Fig. 2). The trends following addition of Triton X-100 to the soil are of particular interest. The non-ionic surfactant greatly decreased the residual concentrations of DDT in the bulk soil while increasing the concentrations in the rhizosphere soil. Earlier studies (Kile and Chiou, 1989) have found that surfactants such as the Triton series and Brij35 significantly enhanced DDT solubility in soils owing to micelle formation. Increased solubility of DDT in soil as well as enhanced plant uptake of water facilitated by AM colonization (Morales Vela et al., 2007) may promote mass flow of DDT towards roots and sequestration in the rhizosphere, a soil zone which may promote DDT degradation and may also contain ample sites for adsorption of POPs on organic matter. Furthermore, formation of abundant extraradical mycelium by AM colonization can also benefit the sequestration of DDT in the rhizosphere zone. The rhizosphere therefore acts as a sink for DDT. This could be very important in phytoremediation because sequestration of POPs in the soil and limited bioavailability are important obstacles in the application of bioremediation methods.

Phytoremediation of organic pollutants depends on plantmicrobe interactions in the rhizosphere (Joner and Leyval, 2003b). We observed a pronounced influence of the AM fungus on soil microbial abundance. It is now well established that AM fungi modify root functions (i.e. root exudation), change carbohydrate metabolism of the host plant and influence rhizosphere populations (Duponnois et al., 2005). Furthermore, AM fungi can exude substances that have a selective effect on the microbial community in rhizosphere soil and thus modify the microbial communities. Previous studies (Stelmack et al., 1999; Chen et al., 2000) have demonstrated inhibitory effects of non-ionic surfactants on bacterial growth, even under the critical micelle concentration. However, we did not find any significant 

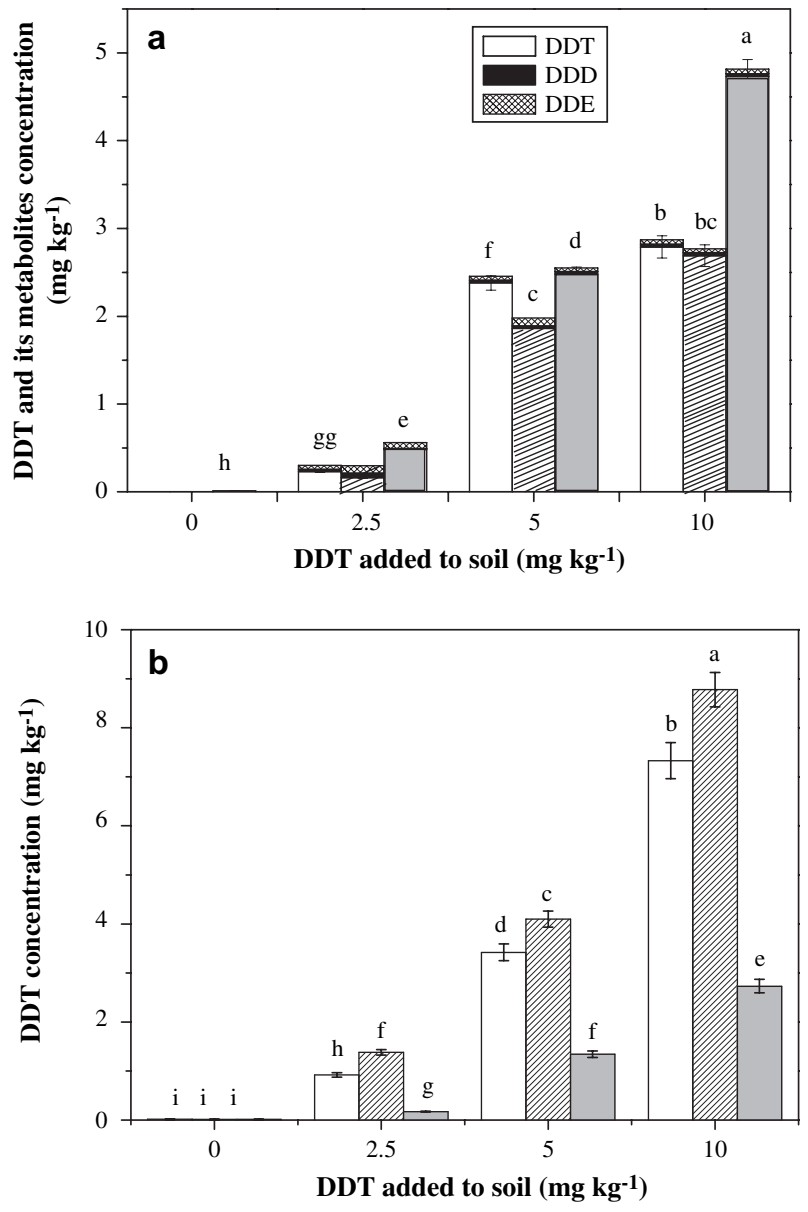

Fig. 2. Total DDT concentrations in (a) rhizosphere and (b) bulk soil. Data are means of three replicates. Non-mycorrhizal ( $\square$ ); Mycorrhizal (שדוC); Mycorrhiza + surfactant $(\square)$. Bars, standard errors. Values followed by the same letter are not significantly different according to Duncan's multiple range test at the $5 \%$ level.



Fig. 3. DDT adsorbed on alfalfa roots. Results are expressed as percentage of DDT adsorbed on roots $(n=3)$. Bars, standard errors.

difference in the microbial counts $(p>0.05)$ between the mycorrhizal and mycorrhizal plus surfactant treatments. Negative effects of surfactant application might be alleviated by AM colonization.

\section{Conclusions}

To our knowledge, the present study is the first to report the effects of arbuscular mycorrhizal colonization combined with application of surfactant to the soil on DDT uptake by plants and DDT dissipation in the soil. AM colonization assisted in the uptake of DDT by alfalfa roots and the combined effects of AM colonization and Triton X-100 increased the accumulation of DDT in both the roots and shoots. In addition, Triton

Table 2

Mean bacterial and fungal counts (CFU/g) and soil dehydrogenase activity in rhizosphere soil ${ }^{\mathrm{a}}$ (mean $\pm \mathrm{SE}, n=3$ )

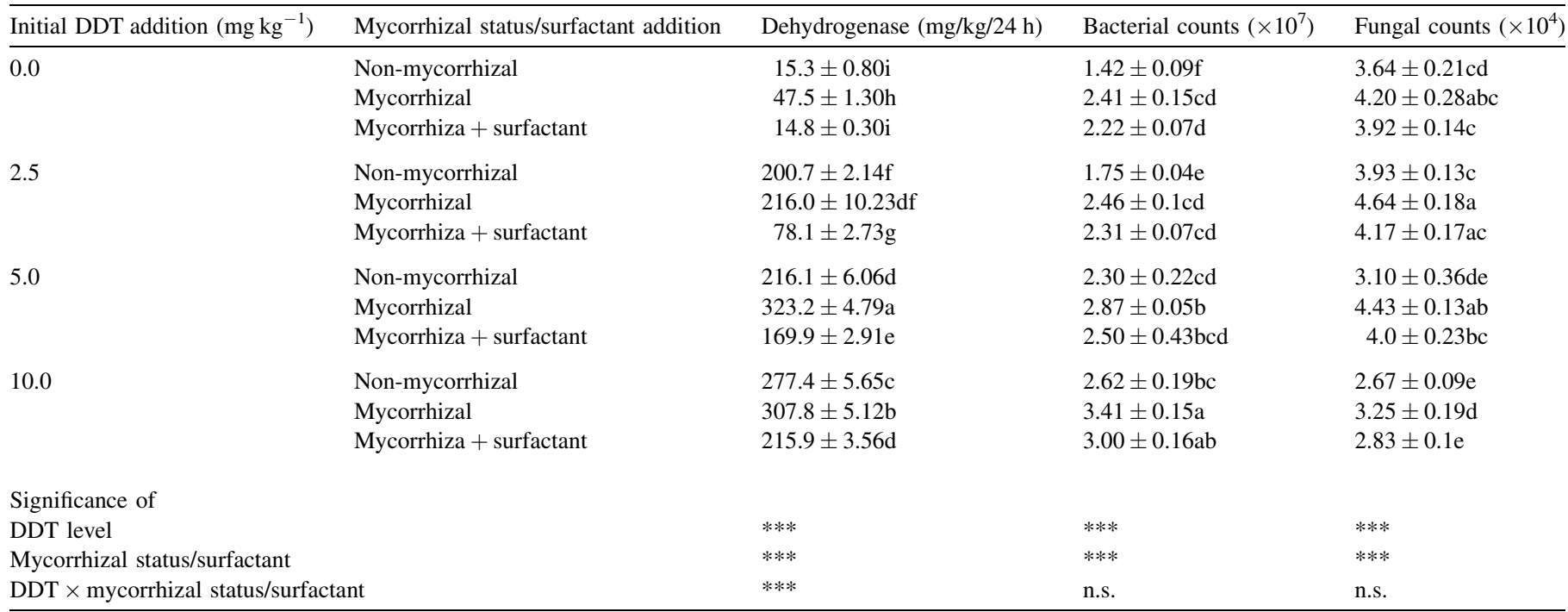

*** Significant by analysis of variance at $p<0.001$.

n.s., Not significant.

a Values followed by the same letter within a column are not significantly different according to Duncan's multiple range test at the $5 \%$ level. 
X-100 increased the mobility and thereby the transport of DDT from the bulk soil to the rhizosphere, an effect which may have promoted both plant uptake and soil degradation of DDT. The combined use of AM inoculum and surfactants may have some potential as a biotechnological approach for the decontamination of soils contaminated with organic pollutants. However, detailed and comprehensive studies on the selection of plant species, AM fungi and surfactants will be required to effective remediation methods under field conditions.

\section{Acknowledgements}

This work was funded by the National Natural Science Foundation of China (Project 20677072, 20621703) and the Hi-tech Research and Development Program of China (Project 2006AA06Z349).

\section{References}

Binelli, A., Provini, A., 2003. DDT is still a problem in developed countries: the heavy pollution of Lake Maggiore. Chemosphere 52, 717-723.

Boldrin, B., Tiehm, A., Fritzsche, C., 1993. Degradation of phenanthrene, fluorene, fluoranthene, and pyrene by a Mycobacterium species. Applied and Environmental Microbiology 59, 1927-1930.

Chen, B.L., Johnson, E.J., Chefetz, B., Zhu, L.Z., Xing, B.S., 2005. Sorption of polar and nonpolar aromatic organic contaminants by plant cuticular materials: role of polarity and accessibility. Environmental Science \& Technology 39, 6138-6146.

Chen, P., Pickard, M.A., Gray, M.R., 2000. Surfactant inhibition of bacterial growth on solid anthracene. Biodegradation 11, 341-347.

Chen, S.H., Xu, F.L., Dawson, R., Jiao, X.C., Tao, S., 2007. Adsorption and absorption of dichlorodiphenyltrichloroethane (DDT) and metabolites (DDD and DDE) by rice roots. Environmental Pollution 147, 256-261.

Dick, R.P., Breakwell, D.P., Turco, R.F., 1996. Soil enzyme activities and biodiversity measurements as integrative microbiological indicators. In: Doran, J.W., Jones, A.J. (Eds.), Methods of Soil Analysis: Part 2. Microbiological and Biochemical Properties. Soil Science Society of America, Special Publication, vol. 49. SSSA, Madison, WI, pp. 247-272.

Duponnois, R., Colombet, A., Hien, V., Thioulouse, J., 2005. The mycorrhizal fungus Glomus intraradices and rock phosphate amendment influence plant growth and microbial activity in the rhizosphere of Acacia holosericea. Soil Biology and Biochemistry 37, 1460-1468.

Giovannetti, M., Mosse, B., 1980. Evaluation of techniques for measuring vesicular arbuscular mycorrhizal infection in roots. New Phytologist 84, 489-500.

Gong, Z.M., Tao, S., Xu, F.L., Dawson, R., Liu, W.X., Cui, Y.H., Cao, J., Wang, X.J., Shen, W.R., Zhang, W.J., Qing, B.P., Sun, R., 2004. Level and distribution of DDT in surface soils from Tianjin, China. Chemosphere $54,1247-1253$.

Huang, H.L., Zhang, S.Z., Shan, X.Q., Chen, B.D., Zhu, Y.G., Bell, J.N.B., 2007. Effect of arbuscular mycorrhizal fungus (Glomus caledonium) on the accumulation and metabolism of atrazine in maize (Zea mays L.) and atrazine dissipation in soil. Environmental Pollution 146, 452-457.

Joner, E.J., Johansen, A., de la Cruz, M.A.T., Szolar, O.J.H., Loibner, A., Portal, J.M., Leyval, C., 2001. Rhizosphere effects on microbial community structure and dissipation and toxicity of polycyclic aromatic hydrocarbons (PAHs) in spiked soil. Environmental Science \& Technology 35, 2773-2777.

Joner, E.J., Leyval, C., 2003a. Phytoremediation of organic pollutants using mycorrhizal plants: a new aspect of rhizosphere interactions. Agronomie $23,495-502$

Joner, E.J., Leyval, C., 2003b. Rhizosphere gradients of polycyclic aromatic hydrocarbon (PAH) dissipation in two industrial soils and the impact of arbuscular mycorrhiza. Environmental Science \& Technology 37, 2371-2375.

Kantachote, D., Singleton, I., Naidu, R., McClure, N., Megharaj, M., 2004. Sodium application enhances DDT transformation in a long-term contaminated soil. Water, Air, and Soil Pollution 154, 115-125.

Kile, D.E., Chiou, C.T., 1989. Water solubility enhancements of DDT and trichlorobenzene by some surfactants below and above the critical micelle concentration. Environmental Science \& Technology 23, 832-838.

Leyval, C., Binet, P., 1998. Effect of polyaromatic hydrocarbons in soil on arbuscular mycorrhizal plants. Journal of Environmental Quality 27, 402-407.

Li, Q.L., Zhu, T., Qiu, X.H., Hu, J.X., Vighi, M., 2006. Evaluating the fate of $p, p^{\prime}$-DDT in Tianjin, China using a non-steady-state multimedia fugacity model. Ecotoxicology and Environmental Safety 63, 196-203.

Lunney, A.I., Zeeb, B.A., Reimer, K.J., 2004. Uptake of weathered DDT in vascular plants: potential for phytoremediation. Environmental Science \& Technology 38, 6147-6154.

Lynch, J.M., 1990. Soil Rhizosphere. John Wiley and Sons, New York.

Morales Vela, G., Molinero-Rosales, N., Ocampo, J.A., García Garrido, J.M., 2007. Endocellulase activity is associated with arbuscular mycorrhizal spread in pea symbiotic mutants but not with its ethylene content in root. Soil Biology and Biochemistry 39, 786-792.

Rhodes, J.D., 1982. Cation Exchange Capacity. In: Page, A.L., Miller, R.H., Keeney, D.R. (Eds.), Methods of Soil Analysis. Part 2: Chemical and Microbiological Properties. American Society of Agronomy, Madison, WI, pp. $149-158$.

Stelmack, P.L., Gray, M.R., Pickard, M.A., 1999. Bacterial adhesion to soil contaminants in the presence of surfactants. Applied and Environmental Microbiology 65, 163-168.

Smith, S.E., Read, D.J., 1997. Mycorrhizal Symbiosis, second ed. Academic Press, London, 605 pp.

Srivastava, S.C., 1992. Influence of soil properties on microbial C, N, and P in dry tropical ecosystems. Biology and Fertility of Soils 13, 176-180.

Stucki, G., Alexander, M., 1987. Role of dissolution rate and solubility in biodegradation of aromatic compounds. Applied and Environmental Microbiology 53, 292-297.

Suresh, B., Ravishankar, G.A., 2004. Phytoremediation: A novel and promising approach for environmental clean-up. Critical Reviews in Biotechnology $24,97-124$.

Vieira, E.D.R., Torres, J.P.M., Malm, O., 2001. DDT environmental persistence from its use in a vector control program: a case study. Environmental Research 86, 174-182.

White, J.C., 2002. Differential bioavailability of field-weathered $p, p^{\prime}$-DDE to plants of the Cucurbita and Cucumis genera. Chemosphere 49, 143-152.

White, J.C., Parrish, Z.D., Gent, M.P.N., Iannucci-Berger, W., Eitzer, B.D., Isleyen, M., Mattina, M.I., 2006. Soil amendments, plant age, and intercropping impact $p, p^{\prime}$-DDE bioavailability to Cucurbita pepo. Journal of Environmental Quality 35, 992-1000.

Zhou, W.J., Zhu, L.Z., 2005. Solubilization of polycyclic aromatic hydrocarbons by anionic-nonionic mixed surfactant. Colloids and Surfaces A: Physicochemical and Engineering Aspects 255, 145-152.

Zhu, L.Z., Chen, B.L., Tao, S., Chiou, C.T., 2003. Interactions of organic contaminants with mineral-adsorbed surfactants. Environmental Science \& Technology 37, 4001-4006. 